\title{
Estimation of the seismic hazard parameters for various sites in Greece using a probabilistic approach
}

\author{
I. D. Banitsiotou ${ }^{1}$, T. M. Tsapanos ${ }^{1}$, V. N. Margaris $^{2}$, and P. M. Hatzidimitriou ${ }^{1}$ \\ ${ }^{1}$ Aristotle University of Thessaloniki, School of Geology, Geophysical Laboratory, 54124 Thessaloniki, Greece \\ ${ }^{2}$ ITSAK, Georgikis Sxolis 46, 55102 Finikas, Thessaloniki, Greece
}

Received: 25 November 2003 - Revised: 27 February 2004 - Accepted: 2 March 2004 - Published: 28 May 2004

\begin{abstract}
The probabilistic approach that was recently introduced by Kijko and Graham $(1998,1999)$ was applied for the estimation of seismic hazard for various sites in Greece in terms of peak ground acceleration (PGA) and peak ground velocity (PGV). These sites represent geographically cities of Greece among which are the capital of Greece and some others with high, intermediate and low seismicity. The approach allows the use of earthquake catalogues with incomplete reported historical and complete instrumental data, the consideration of different magnitude thresholds, and the incorporation of magnitude uncertainties. One of the advantages of the method is that it does not require any determination of seismic zones. The estimated values of PGA for return periods of 476 years were grouped in 4 categories, the same ones used in the seismic hazard map for the New Seismic Code of Greece. Comparison results were quite interesting and very encouraging concerning the reliability of this probabilistic approach.
\end{abstract}

\section{Introduction}

Most of the scientific work done in Greece concerning seismic studies, is the geographical distribution of the maximum observed intensity (Galanopoulos and Delibasis, 1972) the maximum expected intensity (Shebalin et al., 1976; Papaioannou, 1984; Papazachos et al., 1985), peak ground acceleration or velocity (Algermissen et al., 1976; Drakopoulos and Makropoulos, 1983; Papaioannou, 1984; Makropoulos and Burton, 1985) and the duration of the strong motion (Margaris et al., 1990; Papazachos et al., 1992). The separation of Greece and the surrounding area in several seismogenic sources (Algermissen et al., 1976,; Papazachos, 1980; Hatzidimitriou, 1984; Papazachos et al., 1985; Makropoulos et al., 1988; Papazachos and Papazachou, 1989), the application of the method suggested by Cornell (1968) and the use of a computer program written by McGuire (1976) was

Correspondence to: T. M. Tsapanos

(tsapanos@geo.auth.gr) the basis of all the studies mentioned above and many more dealing with the same subject.

The seismic activity in the broad Aegean Area is extremely high and much has occurred within the historical period. One would, therefore, expect a considerable amount of seismological information to be available. However, the incompleteness of the data, even for earthquakes of large magnitude, makes the existing historical catalogues unsuitable for use in seismic hazard evaluation based on most methods proposed. Nevertheless, Kijko and Sellevoll $(1987,1989)$ have developed an approach utilizing the information on strong events contained in the macroseismic part of the catalogue as well as that contained in the complete catalogue.

There are two different approaches that one can use in order to make a seismic hazard analysis, the deterministic and the probabilistic. The first one is a more conservative analysis that accepts the worse scenario of seismic hazard. This is the reason why the deterministic analysis is used mainly in structures that require very high safety measures, as nuclear plants, dams etc. The second one is called probabilistic analysis and accepts uncertainties in the earthquake magnitude, the location and time of generation.

The methodology that was used in this study is a probabilistic analysis and was proposed by Kijko and Graham $(1998,1999)$ in an attempt to try and solve the two main difficulties that all probabilistic analysis have, the incompleteness of the seismic catalogues and the need of definition of the seismic zones. The new methodology combines the best features of the deductive (Cornell, 1968) and non- parametric historic (Veneziano et al., 1984) procedures and in many cases is free from their main disadvantages.

\section{Data used}

The data used in the present study are from the data bank of the Geophysical Laboratory of the University of Thessaloniki (GLUT). Many efforts have been made during the past four decades to publish catalogues of earthquakes in Greece and the adjacent area (Galanopoulos, 1953, 1960, 1963; Karnik, 
Table 1. Magnitude completeness catalogues (Papazachos et al., 2000).

\begin{tabular}{rc}
\hline Period of years & Magnitude threshold \\
\hline 550 B.C. -1500 & $M_{w} \geq 8.0$ \\
1501-1844 & $M_{w} \geq 7.3$ \\
$1845-1910$ & $M_{w} \geq 6.0$ \\
$1911-1949$ & $M_{w} \geq 5.0$ \\
$1950-1963$ & $M_{w} \geq 4.5$ \\
$1964-1980$ & $M_{w} \geq 4.3$ \\
$1981-1999$ & $M_{w} \geq 4.0$ \\
\hline
\end{tabular}

1969, 1971; Comninakis and Papazachos, 1978, 1986, 1989; Makropoulos, 1978; Makropoulos et al., 1989; Papazachos and Papazachou, 1989, 1997; Papazachos et al., 1998). Using these data Papazachos et al. (2000) (publication of Geophysical Laboratory of Thessaloniki) formed a seismic catalogue (Fig. 1), which contains more than 60000 earthquakes for that area during 550 B.C. - 1999 with magnitudes $2.0 \leq M_{w} \leq 8.3$ and is divided in subcatalogues according to the completeness of the magnitude in different time periods (Table 1). It is worth noticing that also the National Observatory of Athens (NOA) publishes catalogues of events occurring in the broad Aegean area (www.gein.noa.gr).

Furthermore, the same authors (Papazachos et al., 2000) estimated the corresponding error in the magnitude of shallow earthquakes and their epicenters is less than 0.25 and $20 \mathrm{~km}$ for the instrumental period 1911-1999, while for the historic period (550 B.C. - 1910) is 0.35 and $30 \mathrm{~km}$, respectively.

\section{Methodology and results}

In order to study the attenuation relations of the strong ground motion at first were used relations from the other areas (Algermissen et al., 1976; Makropoulos, 1978; Makropoulos and Burton, 1985) but later studies used the attenuation relations that were derived for Greece and the adjacent area (Papaioannou, 1984,1986; Papoulia and Stavrakakis, 1990; Theodulidis, 1991).

In an attempt to evaluate the studies done on that area many papers have been published (Drakopoulos and Makropoulos, 1983, 1985; Drakopoulos et al., 1986; Makropoulos et al., 1988, Stavrakakis, 1988; Drakopoulos and Stavrakakis, 1990; Papazachos et al., 1990).

Earlier works in the seismic hazard assessment for Greece and the adjacent area have been published by many researchers. Interesting results on simulation of strong ground motion were derived by Stavrakakis et al. (1986), Makropoulos et al. (1990), Margaris (1994), Theodulidis and Bard (1995).
Table 2. The $b$ values used (Hatzidimitriou et al., 1994), the radius, $L$, used for each city and the maximum observed magnitude $m_{\max }^{\mathrm{obs}}$ for each area (Banitsiotou, 2003).

\begin{tabular}{|c|c|c|c|c|c|}
\hline Cities & $\varphi^{\circ}$ & $\lambda^{\circ}$ & $b$ value & $\begin{array}{c}L \\
(\mathrm{~km})\end{array}$ & $\begin{array}{r}\text { Mmax } \\
(\text { obs })\end{array}$ \\
\hline Alexandroupoli & 40.85 & 25.87 & 0.7 & 53 & 7 \\
\hline Amfissa & 38.52 & 22.38 & 1 & 53 & 7 \\
\hline Argostoli & 38.17 & 20.48 & 1.1 & 75 & 7.3 \\
\hline Arta & 39.15 & 20.98 & 1.1 & 47 & 6.9 \\
\hline Athens & 37.98 & 23.72 & 0.9 & 26 & 6.4 \\
\hline Athos & 40.25 & 24.23 & 0.8 & 75 & 7.3 \\
\hline Chalkida & 38.47 & 23.58 & 0.9 & 53 & 7 \\
\hline Chania & 35.52 & 24.02 & 1 & 42 & 6.8 \\
\hline Chios & 38.38 & 26.13 & 0.9 & 42 & 6.8 \\
\hline Edessa & 40.8 & 22.05 & 0.8 & 33 & 6.6 \\
\hline Florina & 40.78 & 21.4 & 0.9 & 33 & 6.6 \\
\hline Igoumenitsa & 39.5 & 20.27 & 1.1 & 47 & 6.9 \\
\hline Ioannina & 39.67 & 20.85 & 1 & 26 & 6.4 \\
\hline Irakleio & 35.35 & 25.12 & 1 & 66 & 7.2 \\
\hline Kalamata & 37.03 & 22.1 & 1.1 & 47 & 6.9 \\
\hline Karditsa & 39.37 & 21.92 & 1 & 42 & 6.8 \\
\hline Karpenisi & 38.92 & 21.8 & 1 & 53 & 7 \\
\hline Kastoria & 40.52 & 21.27 & 1 & 33 & 6.6 \\
\hline Katerini & 40.27 & 22.5 & 0.9 & 33 & 6.6 \\
\hline Kavala & 40.93 & 24.42 & 0.7 & 53 & 7 \\
\hline Kerkira & 39.62 & 19.92 & 1.1 & 47 & 6.9 \\
\hline Kilkis & 40.98 & 22.88 & 0.8 & 60 & 7.1 \\
\hline Korinthos & 37.93 & 22.92 & 1 & 53 & 7 \\
\hline Kozani & 40.3 & 21.78 & 0.9 & 33 & 6.6 \\
\hline Lamia & 38.9 & 22.43 & 1 & 53 & 7 \\
\hline Larisa & 39.63 & 22.42 & 0.9 & 53 & 7 \\
\hline Leukada & 38.82 & 20.7 & 1.1 & 60 & 7.1 \\
\hline Livadia & 38.43 & 22.87 & 1 & 53 & 7 \\
\hline Mesologi & 38.37 & 21.42 & 1.1 & 42 & 6.8 \\
\hline Mitilini & 39.1 & 26.57 & 0.8 & 66 & 7.2 \\
\hline Nafplio & 37.57 & 22.8 & 1 & 47 & 6.9 \\
\hline Patra & 38.27 & 21.73 & 1.1 & 42 & 6.8 \\
\hline Pirgos & 37.67 & 21.43 & 1.1 & 47 & 6.9 \\
\hline Poligiros & 40.37 & 23.43 & 0.8 & 33 & 6.6 \\
\hline Preveza & 38.95 & 20.75 & 1.1 & 47 & 6.9 \\
\hline Rethimno & 35.37 & 24.48 & 1 & 42 & 6.8 \\
\hline Rhodos & 36.43 & 28.23 & 1 & 134 & 7.8 \\
\hline Samos & 37.75 & 26.98 & 0.9 & 42 & 6.8 \\
\hline Serres & 41.08 & 23.55 & 0.7 & 53 & 7 \\
\hline Sparti & 37.07 & 22.42 & 1 & 42 & 6.8 \\
\hline Thessaloniki & 40.63 & 22.93 & 0.8 & 33 & 6.6 \\
\hline Tripoli & 37.5 & 22.37 & 1 & 47 & 6.9 \\
\hline Veroia & 40.52 & 22.2 & 0.8 & 33 & 7 \\
\hline Volos & 39.37 & 22.97 & 0.9 & 53 & 7.1 \\
\hline Zakinthos & 37.78 & 20.88 & 1.1 & 59 & 6.6 \\
\hline
\end{tabular}

In order to estimate the seismic hazard parameters for each one of the studied sites the main seismic catalogue of Greece was divided in subcatalogues. Afterwards, the seismic zones of Greece as proposed by Papaioannou and Papazachos (2000) were used to get the maximum observed 


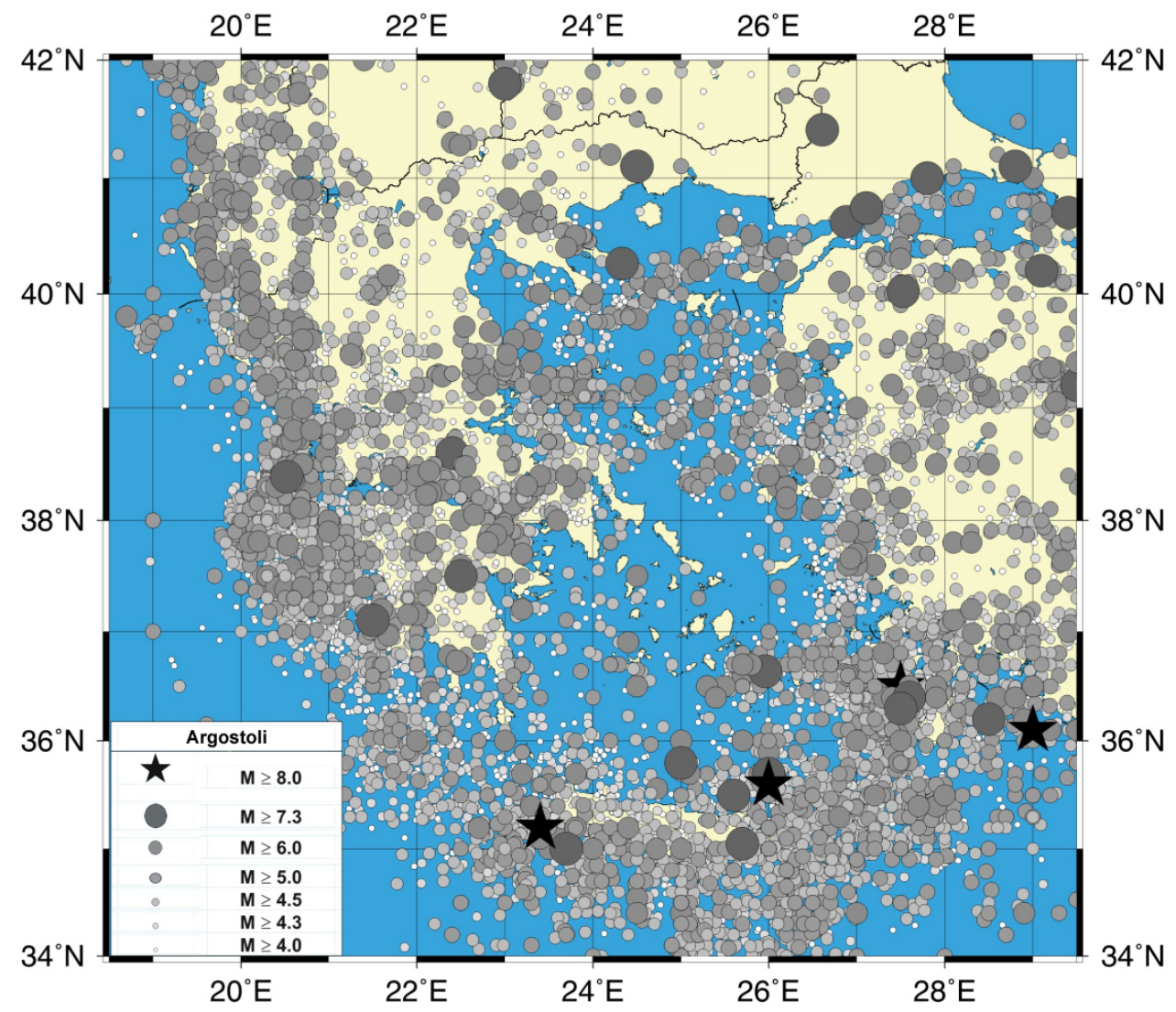

Fig. 1. Seismicity of Greece based on the seismic catalogue of Papazachos et al., 2000

magnitude, $m_{\max }^{\text {obs }}$, of each one of them. The values of the $m_{\max }^{\text {obs }}$ were used as $M_{w}$ in the relation of Papazachos (1989):

$\log L=0.51 M_{w}-1.85$

which provided the radius, $L$, for the circular area where the seismic data were taken for each site of study. The radius estimated as well as the maximum observed magnitude, $m_{\max }^{\mathrm{obs}}$, for every site are shown in Table 2.

It must be noted that the option of different radius areas for every site was considered only after using standard radius of 50,75 and $100 \mathrm{~km}$. The results that were estimated in those cases made it clear that it was compulsory to have different radius for different sites depending on the seismicity of the area, because in areas of low seismicity the seismic catalogue of radius $50 \mathrm{~km}$ was very small, giving results with big errors. On the other hand, for radius of 100 and $75 \mathrm{~km}$ in many cases the results were overestimated smoothing the seismicity of each site to a seismicity of larger area.

Besides these two parameters ( $m_{\max }^{\text {obs }}$ and $L$ ) also parameter $b$ has variable values at sites. The values of parameter $b$ that were used in this study are the ones proposed by Hatzidimitriou et al. (1994). Additionally, we took the earthquakes for the time-period 1994-1999 intending to find the new values of $b$ parameter. The difference between the ones proposed by Hatzidimitriou et al. (1994) and the new ones was negligible.
So, all the data mentioned above were used in the first phase of the methodology in a computer program computed by Kijko, which gave the maximum possible magnitude $m_{\max }^{\text {pos }}$ for each site. The values of $m_{\max }^{\text {pos }}$ were used in the second phase for the estimation of the seismic hazard parameters (PGA, PGV).

The attenuation relations that were used for the estimation of the values of Peak Ground Acceleration (PGA) Eq. (2) and Peak Ground Velocity (PGV) Eq. (3) were the ones proposed by Margaris et al. (2001).

$$
\begin{aligned}
\ln (P G A)= & 3.52+0.70 \cdot M \\
& -1.14 \cdot \ln \left(R^{2}+h_{0}^{2}\right)^{1 / 2}+0.12 \cdot S \pm 0.70 \\
\ln (P G V)= & -2.08+1.13 \cdot M \\
& -1.11 \cdot \ln \left(R^{2}+h_{0}^{2}\right)^{1 / 2}+0.29 \cdot S \pm 0.80
\end{aligned}
$$

where PGA is acceleration measured in units of gravity, $(\mathrm{g})$, $\mathrm{PGV}$ is velocity measured in $\mathrm{cm} / \mathrm{s}, M$ is the earthquake magnitude, $R$ is the epicentral distance, $h_{0}$ is the "effective" depth of an event, which is, the depth where seismic energy is released and gets values $h_{0}=7 \mathrm{~km}$ for PGA and $h_{0}=6 \mathrm{~km}$ for PGV and $S$ is a factor of the soil conditions with values 0 , 1 or 2 when it refers to hard rock, intermediate soil and soft soil, respectively. In the present study we used only intermediate soil conditions, $S=1$. 


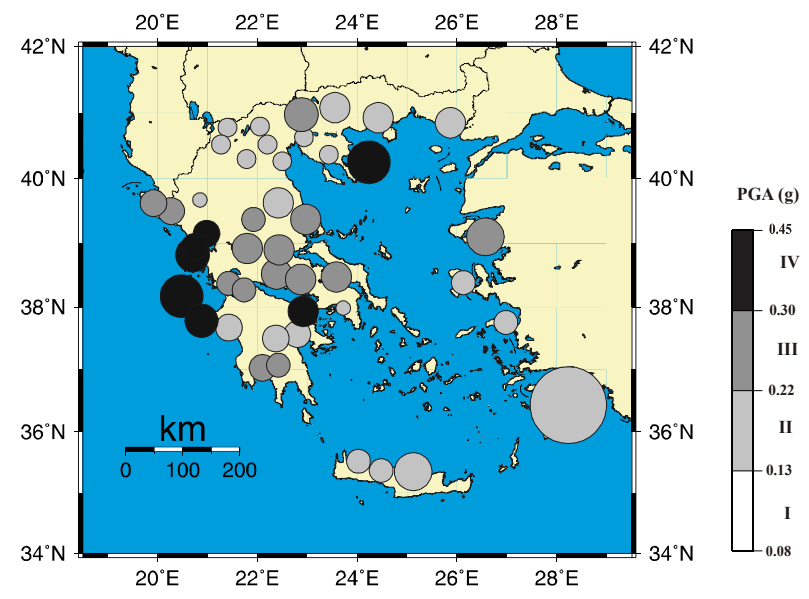

Fig. 2. Seismic hazard map in terms of Peak Ground Acceleration (PGA) for return period 476 years (Banitsiotou, 2003).

The results of the estimated PGA for a return period of 476 years are grouped in 4 categories and are shown in Fig. 2 . The limits of values that were used in Fig. 2 are defined by the ones used in the map with the seismic hazard zones of Greece (Fig. 4) given as common report by the Geophysical Lab of A.U.TH and I.T.S.A.K. (2002) so that can be comparison between these two maps. In the Fig. 2 it is also depicted with a colored circle the area around each city that is possible to have such ground acceleration. The circle in each city has a diameter equal to the estimated radius $L$, shown in Table (2). Values of PGA higher than $0.3 \mathrm{~g}$ were estimated for the Ionian Islands and specifically the island of Zakinthos, Cephalonia and Lefkada but also for the area around the city of Corinth and the peninsula of Atho. Values of PGA between 0.22 and $0.3 \mathrm{~g}$ were estimated for the majority of the cities in central Greece while lower values than $0.22 \mathrm{~g}$ were estimated for the north part of Greece and also the most of Aegean islands that were in this study.

In Fig. 3 are shown the results of the Peak Ground Velocity (PGV) for a return period of 476 years as well as the area that will possibly have an equal value of PGV. The map of Fig. 3 shows higher values in the Ionian Islands, values between $15-25 \mathrm{~cm} / \mathrm{s}$ in the central part of Greece and lowers than $15 \mathrm{~cm} / \mathrm{s}$ in the north and south Greece.

The PGA and PGV values estimated for the regions of Crete and Dodecanese Islands, South Aegean Sea, are lower with respect to real ones since intermediate depth earthquakes, taking place in these regions, were not considered given that in our analysis only shallow shocks have been taken into account. So, for the cities where earthquakes of intermediate depth occur the estimated values are not correct.

\section{Comparison with similar studies and discussion}

The results of PGA that are shown in Fig. 2 were compared with the results given in the seismic hazard map of Greece shown in Fig. 4 which was given as a common report by the Geophysical Lab of of A.U.TH and I.T.S.A.K. (2002) . The

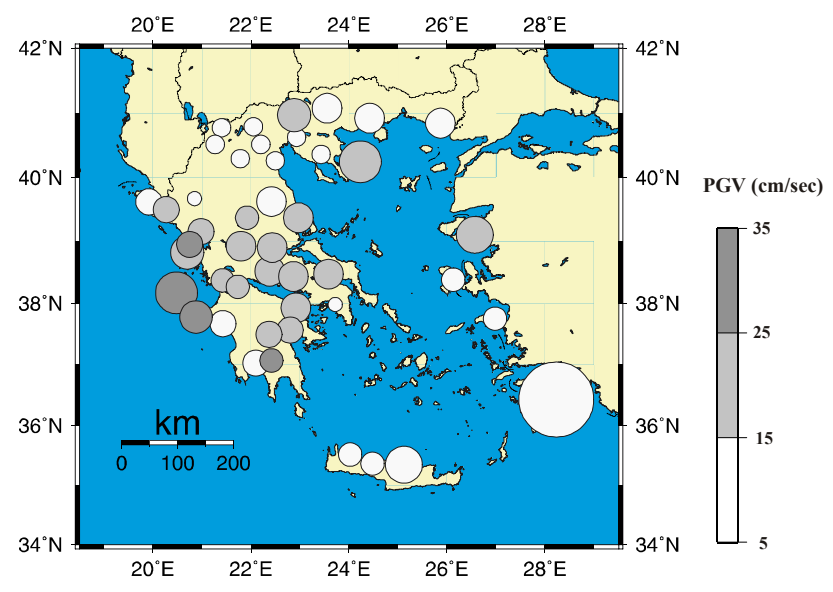

Fig. 3. Seismic hazard map in terms of Peak Ground Velocity (PGV) for return period 476 years (Banitsiotou, 2003).

summarized results of the comparison are shown in Table 3. As we can see in Table 3 the vast majority of the cities representing a $64,4 \%$, which were studied, are grouped in the same category in both Figs. 2 and 4. On the other hand, the cities with differences in the grouping are shown with gray color. It must be noted that the difference in category in some of the cities doesn't mean necessarily big difference in the values. For example, for the city of Samos the estimated value in the present study was $0.2195 \mathrm{~g}$ and so it is in category II when the limit for category III where the report of the Geophysical Laboratory and I.T.S.A.K. (2002) situates it, is $0.22 \mathrm{~g}$.

The values estimated in this study were also compared with the values of PGA and PGV estimated with the methodology of McGuire (1976). The results of the comparison were very encouraging and the histograms of Figs. 5 and 6 show the frequency of the difference in the estimated values by these two methodologies for PGA and PGV, respectively.

\section{Conclusions}

The probabilistic methodology proposed by Kijko and Graham (1999) was applied for the estimation of the Peak Ground Acceleration (PGA) and Peak Ground Velocity (PGV) for 45 sites in Greece. The magnitudes that were used in the earthquake catalogues are $4.0 \leq M \leq 8.3$ and the attenuation relations employed were the ones proposed by Margaris et al. (2001).

The results were plotted in maps (see Figs. 2 and 3) and were compared with the ones given by the methodology of McGuire (1976) giving a very encouraging output. The map with the results for PGA (Fig. 2) was compared with the one given as a common report by the Geophysical Lab of A.U.TH and ITSAK (2002) (Fig. 4) and the results were summarized in Table 3 were most of the studied sites have good agreement with that report.

So, as a conclusion we can say that we have a tool for seismic hazard assessment, which in some cases is promising and comparable with corresponding classical methods. 


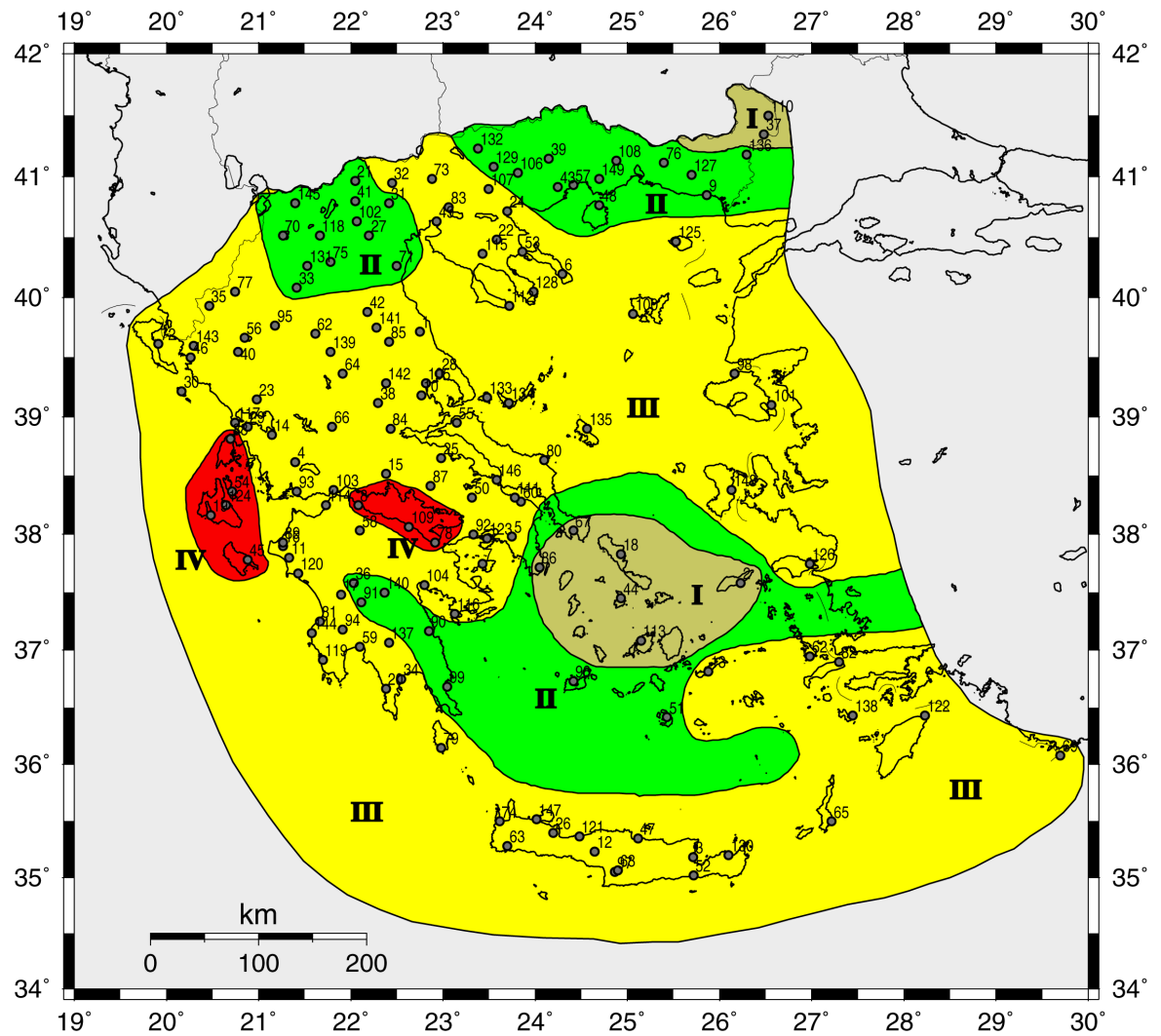

Fig. 4. Map with the seismic hazard zones of Greece (Geophysical Lab A.U.TH and I.T.S.A.K., 2002).

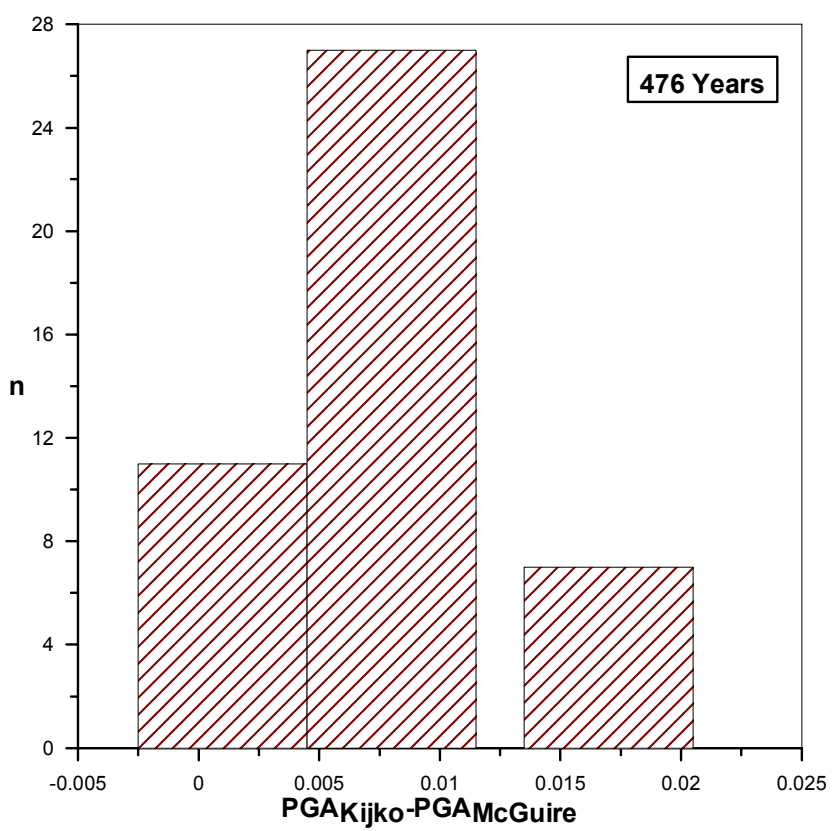

[g]

Fig. 5. Histograms of the difference in the estimated values of PGA with the methodology of Kijko and Graham (1999) and McGuire (1976) for return period of 476 years (Banitsiotou, 2003).

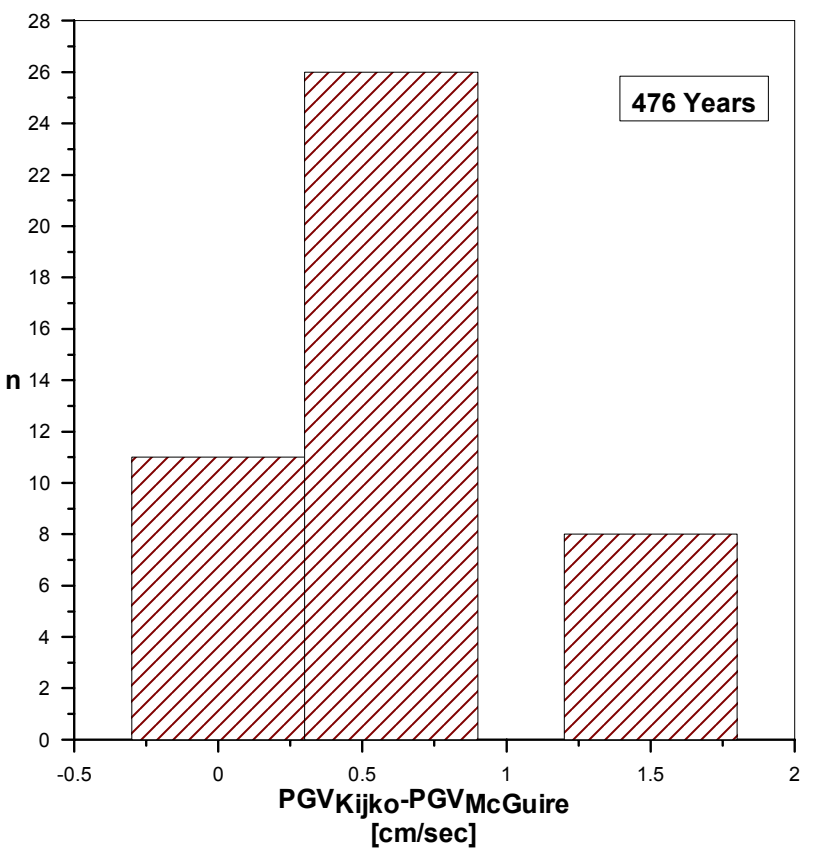

Fig. 6. Histograms of the difference in the estimated values of PGV with the methodology of Kijko and Graham (1999) and McGuire (1976) for return period of 476 years (Banitsiotou, 2003). 
Table 3. Summarized results of PGA with return period 476 years of the present study and the one done for the New Seismic Code of Greece (Banitsiotou, 2003).

\begin{tabular}{|c|c|c|c|}
\hline City & PGA (g) & Present Study & N.S.C.G. \\
\hline Alexandroupoli & 0.15 & II & II \\
\hline Athina & 0.14 & II & III \\
\hline Athos & 0.31 & IV & III \\
\hline Amfissa & 0.26 & III & III \\
\hline Argostoli & 0.41 & IV & IV \\
\hline Arta & 0.33 & IV & III \\
\hline Veroia & 0.17 & II & II \\
\hline Volos & 0.28 & III & III \\
\hline Edessa & 0.17 & II & II \\
\hline Zakinthos & 0.38 & IV & IV \\
\hline Igoumenitsa & 0.26 & III & III \\
\hline Irakleio & 0.16 & II & III \\
\hline Thessaloniki & 0.17 & II & III \\
\hline Ioannina & 0.20 & II & III \\
\hline Kavala & 0.16 & II & II \\
\hline Kalamata & 0.22 & III & III \\
\hline Karditsa & 0.27 & III & III \\
\hline Karpenisi & 0.27 & III & III \\
\hline Kastoria & 0.17 & II & II \\
\hline Katerini & 0.16 & II & II \\
\hline Kerkira & 0.23 & III & III \\
\hline Kilkis & 0.29 & III & III \\
\hline Kozani & 0.17 & II & II \\
\hline Korinthos & 0.31 & IV & IV \\
\hline Lamia & 0.24 & III & III \\
\hline Larisa & 0.16 & II & III \\
\hline Livadia & 0.30 & III & III \\
\hline Lefkada & 0.34 & IV & IV \\
\hline Mesologi & 0.27 & III & III \\
\hline Mitilini & 0.23 & III & III \\
\hline Nafplio & 0.21 & II & III \\
\hline Patra & 0.26 & III & III \\
\hline Poligiros & 0.17 & II & III \\
\hline Preveza & 0.33 & IV & III \\
\hline Pirgos & 0.21 & II & III \\
\hline Rethimno & 0.14 & II & III \\
\hline Rhodos & 0.20 & II & III \\
\hline Samos & 0.22 & II & III \\
\hline Serres & 0.20 & II & II \\
\hline Sparti & 0.25 & III & III \\
\hline Tripoli & 0.22 & II & II \\
\hline Florina & 0.16 & II & II \\
\hline Chalkida & 0.29 & III & III \\
\hline Chania & 0.15 & II & III \\
\hline Chios & 0.21 & II & III \\
\hline
\end{tabular}

Acknowledgements. We would like to acknowledge the logistical support by GMT (Generic Mapping Tools) for the computation of the maps in this study.

Edited by: M. Contadakis

Reviewed by: two referees

\section{References}

Banitsiotou, I. D., Tsapanos, T. M., Hatzidimitriou, P. M., and Margaris, V. N.: Estimation of the seismicity and seismic hazard parameters in the seismogenetic zones of Greece and the adjacent area using the modified Bayesian methodology, Master Dissertation, Aristotle University of Thessaloniki, 93, 2003.

Comninakis, P. E. and Papazachos, B. C.: A catalogue of earthquakes in the Mediterranean and the surrounding area for the period 1901-1975, Publ. Geophys. Lab. Univ. Thessaloniki, 5, 96, 1978.

Comninakis, P. E. and Papazachos, B. C.: A catalogue of earthquakes in Greece and surrounding area for the period 1901-1985, Publ. Geophys. Lab. Univ. Thessaloniki, 1, 167, 1986.

Comninakis, P. E. and Papazachos, B. C.: Aftershock and foreshock sequences in Greece and surrounding area during the period 1911-1985, Publ. Geophys. Lab. Thessaloniki, 5, 156, 1989.

Cornell, C. A.: Engineering Seismic Risk Analysis, Bull. Seism. Soc. Am. 58, 1503-1606, 1968.

Galanopoulos, A. G.: On the intermediate earthquakes in Greece, Bull. Seism. Soc. Am., 43, 159-178,1953.

Galanopoulos, A. G.: A catalogue of shocks with $I o \geq V I$ or $M \geq 5$ for the years 1801-1958, Athens, 119, 1960.

Galanopoulos, A. G.: On mapping of seismic activity in Greece, Annali di Geof., 16, 37-100, 1963.

Geophysical Laboratory of Aristotle University of Thessaloniki and Institute of Engineering Seismology and Earthquake Engineering (ITSAK): Collection and Procession of Seismological data and computation of seismic hazard map of Greece according to the current Greek Seismic Code and Eurocode 8, 38, 2002.

Hamdache, M. and Retief, S. J. P.: Site-Specific Seismic Hazard Estimation in the Main Seismogenic Zones of North Algeria, Pure and Applied Geophysics 158, 1677-1690, 2001.

Hatzidimitriou, P. M., Papazachos, B. C., and Karakaisis, G. F.: Quantitative Seismicity of the Aegean and Surrounding Area, XXIV General Assembly of E.S.C., Athens, 19-24 September 1994, 1, 155-164, 1994.

Kàrnìk, V.: Seismicity of the European Area. Part I, D. Reidel Publishing Company, Dordrecht-Holland, 364, 1969.

Kàrnì, V.: Seismicity of the European Area. Part II, D. Reidel Publishing Company, Dordrecht-Holland, 218, 1971.

Kijko, A. and Graham, G.: Parametric-Historic Procedure for Probabilistic Seismic Hazard Analysis, Part I: Estimation of Maximum Regional Magnitude mmax, Pure and Appl. Geophys., 152, 413-442, 1998.

Kijko, A. and Graham, G.: "Parametric-Historic" Procedure for Probabilistic Seismic Hazard Analysis, Part II: Assessment of Seismic Hazard at Specified Site, Pure and Appl. Geophys., 154, 1-22, 1999.

Makropoulos, K. C.: The statistics of large earthquake magnitude and an evaluation of Greek seismicity, Ph.D. thesis, Univ. of Edinburgh, 193, 1978.

Makropoulos, K. and Burton, W. P.: Seismic Hazard in Greece, II. Ground Acceleration, Tectonophysics, 117, 259-294, 1985.

Makropoulos, K., Stavrakakis, G., Latoussakis, J., and Drakopoulos, J.: Seismic Zoning Studies in the Area of Greece Based on the Most Perceptible Earthquake Magnitude, Geofizika, 5, 37 48, 1989.

Mantyniemi, P., Tsapanos, T. M., and Kijko, A.: An Estimate of Probabilistic Seismic Hazard for Five Cities in Greece by Using the Parametric-historic Procedure, Engineering Geology, 72, 217-231, 2004. 
Margaris, V., Papazachos, C. B., Papaioannou, Ch. A., Theodulidis, N., Kalogeras, I., and Skarlatoudis, A.: A Ground Motion Attenuation Relations for Shallow Earthquakes in Greece, 12th Europ. Conf. on Earthquake Engineering, in press 2004.

McGuire, R. K.: FORTRAN Computer Program for Seismic Risk Analysis, U.S. Geol. Surv., Open file rep., 76-67, 69, 1976.

Papadopoulos, G. and Kijko, A., Maximum Likelihood Estimation of Earthquake Hazard Parameters in the Aegean Area from Mixed Data, Tectonophysics, 185, 277-194, 1991.

Papaioannou, Ch. A. and Papazachos, B. C.: Time-Independent and Time-Dependent Seismic Hazard in Greece Based on Seismogenic Sources, Bull. Seism. Soc. Am., 90, 1, 22-33, 2000.

Papazachos, B. C.: Measures of the Earthquake size in the area of Greece. 1st Scientific Congress of the Hellinic Geophysical Union, Athens, April 1989, 437-447, 1989.

Papazachos, B. C. and Papazachou, C. B.: The earthquakes of Greece (in Greek), Ziti Publ., Thessaloniki, 356, 1989.
Papazachos, B. C. and Papazachou, C. B.: The earthquakes of Greece, Ziti Publ., Thessaloniki, 304, 1997.

Papazachos, B. C., Karakostas, V. G., Scordilis, E. M., Papazachos, C. B., Papaioannou, Ch. A., and Karakaisis, G. F.: A catalog for the Aegean and Surrounding Area for the Time Period 550 B.C.-1997, Thessaloniki, 1998.

Papazachos, B. C., Comninakis, P. E., Karakaisis, G. F., Karakostas, B. G., Papaioannou, Ch. A., Papazachos, C. B., and Scordilis, E. M.: A catalogue of earthquakes in Greece and surrounding area for the period 550 B.C.-1999, Publ. Geophys. Labor., University of Thessaloniki, 2000.

Tsapanos, T. M.: A Seismic Hazard Scenario for the Main Cities of Crete Island, Greece, Geophys. J. Int., 153, 403-408, 2003.

Veneziano, D., Cornell, C. A., and O'Hara, T.: Historic Method for Seismic Hazard Analysis, Elect. Power Res. Inst., Report, NP3438, Palo Alto, 1984. 